\title{
Major Determinants of Prices Increase of Building Materials on Ghanaian Construction Market
}

\author{
Humphrey Danso*, Nana Kwame Obeng-Ahenkora \\ Department of Construction and Wood Technology, University of Education Winneba, Kumasi, Ghana \\ Email: ^hdanso@uew.edu.gh, dansohumphrey@yahoo.co.uk
}

How to cite this paper: Danso, H. and Obeng-Ahenkora, N.K. (2018) Major Determinants of Prices Increase of Building Materials on Ghanaian Construction Market. Open Journal of Civil Engineering, 8, 142-154.

https://doi.org/10.4236/ojce.2018.82012

Received: April 10, 2018

Accepted: June 12, 2018

Published: June 15, 2018

Copyright $\odot 2018$ by authors and Scientific Research Publishing Inc. This work is licensed under the Creative Commons Attribution International License (CC BY 4.0).

http://creativecommons.org/licenses/by/4.0/

\begin{abstract}
Prices increase of building materials is a common trend in both developed and developing countries. The prices increase of building materials results in high cost of housing.The aim of this study is to identify the major determinants of prices increase of building materials on Ghanaian construction market, and also to assess the relationship between the independent variables of the prices increase. A five-point Likert scale was used for the study; from strongly disagree (1) to strongly agree (5). The variables in the questionnaire were ranked based on the response of the participants of the study using Mean Response Analysis (MRA) statistics. Spearman correlation matrix was used to determine the relationship between the variables of prices increase of building materials. Crude oil prices, energy cost, local taxes and charges, cost of fuel and power supply, high running cost, high prices of raw materials, cost of transportation and the high cost of labour were found to be the major determinants of prices increase of building materials on Ghanaian construction market. The study further found multicollinearity relationship among variables of prices increase of building materials, of which the highest correlation coefficient was found between fast-growing demand due to high global economic growth and over-dependence on imported building materials. The study recommends that further research should be carried out to determine the control measures of increase prices of building materials in Ghana.
\end{abstract}

\section{Keywords}

Building Materials, Construction Market, Cost of Building Materials, Prices Increase

\section{Introduction}

Building materials are materials used in construction work starting from the 
underground to the finishing [1]. Building materials are basic construction products such as cement, bricks, concrete, and aggregates, i.e. sand, rock, and gravel [2]. Prices increase of building materials has become a common global trend, and even the developed countries are not left out. A number of developed countries are in recent times experiencing the problem with prices increase of building materials. According to Jonsson [3], in Sweden, building materials' cost rose by $3.1 \%$, the largest increase in the building material group was in reinforcement steel which price increase by $5.8 \%$, concrete products price rose at $2.7 \%$ and other building material groups also increased. Slowey [4] noted that the numbers from the Bureau of Labour Statistics US revealed a $4.8 \%$ rise in building material prices between February 2016 and February 2017. Building materials cost fluctuate on a daily basis, but the overall trend in recent time has been up [5].

The situation in developing countries is not different, where building materials prices keep increasing. A study by Windapo et al. [6] showed that the price of building materials in South Africa among others have an effect on the cost of the building. The cost of building new houses in Namibia increased considerably between 2008 and 2009 because of a hike in the prices of building materials, like cement [7]. According to Pashardesa and Savva [8] increase in house prices during the period 1988-2008 in Cyprus points to increase in the cost of building materials.

Wagura [9] noted that building materials are expensive in Kenya due to the transport and importation costs. A study by Oladipo and Oni [10] reviewed selected macroeconomic factors impacting building material prices in Nigeria. Huan and Jianhua [11] analysed the factors that cause the price change of building materials in China. Rajaprabha et al. [12] studied the factors affecting the cost of building material in construction projects in India. Nadramia [2] indicated that demographic trends and other indicators are most relevant in the assessment of market conditions for building materials prices. This means studying the factors that cause prices increase of building materials in different countries is relevant because the situation in each country is different. There is the need also to determine the factors that contribute to the prices increase of building materials in Ghana. This study, therefore, investigates the major determinates of prices increase of building materials on Ghanaian construction market, and also assess the relationship between the independent variables.

\section{Literature Review}

The supply of houses is affected by the increase in the costs of building materials [13]. The growth of the construction sector brings with it, the growth in the manufacturing industry for the building materials such as cement and steel [9]. Cost overruns among other factors are often caused by the increasing prices of resources such as building materials [14] [15] [16]. The cost of building a house has rapidly increased with the increase in the cost of construction materials such 
as cement, steel, sand, and piling materials since 2008 [17]. According to Reyes

[5] in the US, prices of building materials increased in 2016 by:

- $13.8 \%$ for oriented strand board (OSB), a type of particle board commonly used in home construction;

- $8.7 \%$ for softwood lumber, commonly used in home construction;

- $5.0 \%$ for gypsum products, such as plaster and plasterboard; and

- $3.5 \%$ for ready-mix concrete, used for projects like foundations and driveways.

Oladipo and Oni [10] established that inflation, exchange rate, import, interest rate, money supply and demand for money have a significant effect on the prices of building materials in Nigeria. Another study conducted in Nigeria by Akanni et al. [18] found that the three most rated factors responsible for the rising cost of building materials are the exchange rate of the Nigeria Naira, cost of fuel and power supply, and changes in government policies and legislation, while fluctuations in the construction cost, reduced volume of construction output and risk of project abandonment were the three most rated implications. A study by Huan and Jianhua [11] identified the value of building materials, supply-demand relationship, national macro policy, the value of money, notes circulation and the influence of the international market as the factors that cause the price change of building materials in China. In South Africa, a study by Windapo and Cattell [19] examined the trends in building material prices and the factors contributing to the increase in prices of building materials. The study found transport costs, crude oil prices, labour costs and energy costs as the factors that affect building material prices.

Rajaprabha et al. [12] found design issues and market condition issues as the major significant factors that cause building materials' prices increase in India. According to Nadramia [2], building materials companies that are able to defend and increase market share are likely to adjust their strategies to evolving market conditions, be innovative, have some pricing advantage, and maintain sales growth and profitability, even during adverse economic conditions. A study by Tupenaite et al. [20] reveals that prices movements in Lithuania's housing sector can largely be explained by economic fundamentals and housing market indicators. The housing supply lag in urban areas has been worsened by the high cost of building materials among others which make decent houses unaffordable to the urban poor who in turn result to makeshift houses [9].

\section{Methodology}

The research design used for this study was a descriptive survey. The population of the study were building material merchants, building contractors and registered quantity surveyors. They constituted the population of the study due to the fact that they are knowledgeable on issues related to pricing of building materials. Snowball and purposive sampling techniques were used to select the sample for collecting data. The snowball technique was adopted for selecting mer- 
chants of building materials to participate in the study. Glen [21] explains snowball sampling as a technique where research participants recruit other participants for a test or study. It is used where potential participants are hard to find. It is called snowball sampling because once you have the ball rolling, it picks up more "snow" along the way and becomes larger and larger. Initially, three merchants of building materials were identified who aided in recruiting others for the study. Purposive sampling technique was also used to select the contractors and quantity surveyors for the study. Contractors and quantity surveyors who were currently involved in construction project works were chosen for the study since they possessed enough information on the current prices of building materials. Three cities were selected for the study, thus Accra, Kumasi and Sunyani. Accra and Kumasi were selected because they are the cities where major construction activities are taking place, while Sunyani was selected to represent cities with less construction activities.

The questionnaire was used to collect data on the major determinants of prices increase of building materials in Ghanaian construction market. A five-point Likert scale was used for the study; from strongly disagree (1) to strongly agree (5). The questionnaire contained items on demographic data and items on the determinants of building materials prices increase. The items on the determinants of building materials prices increase were adopted from literature. The instrument was pilot tested and the reliability coefficient (Cronbach's Alpha) determined was 0.93 which was above the recommended value of 0.7 [22]. The questionnaire was administered to a selected sample of 120, out of which 95 questionnaires were retrieved, representing $79 \%$ response rate.

The variables in the questionnaire were ranked based on the response of the participants using Mean Response Analysis (MRA) statistics. The mean score obtained was based on the five-point Likert scale. The formula for the MRA is:

Mean score $=\left(5 n_{5}+4 n_{4}+3 n_{3}+2 n_{2}+1 n_{1}\right) /\left(n_{5}+n_{4}+n_{3}+n_{2}+n_{1}\right)$ where $\mathrm{n}_{5}, \mathrm{n}_{4}, \mathrm{n}_{3}, \mathrm{n}_{2}, \mathrm{n}_{1}$ = number of respondents who answered from strongly agree to strongly disagree.

This ranking aided in determining which variables play the main role in determining price increase of building materials. The mean ratings were compared with the theoretical mean rating of 4.0 to determine the major determinants of prices increase of building materials in the construction market. Therefore, any mean relating to 4.0 or above indicated the expression of major determinant of the prices increase of building material, while mean values below 4.0 indicated the expression of none major determinants. Also, Spearman correlation matrix with the aid of statistical package for social sciences (SPSS) version 21 was used to determine the relationship between the variables.

\section{Results and Discussion}

\subsection{Demographic Characteristics of the Respondents}

The demographic characteristics of the respondents are shown in Table 1. It 
could be seen that majority $(80 \%)$ of the respondents were males, which indicates male dominant in the construction industry in Ghana as was also found by Danso [23]. 31\% the respondents were less than 30 years of age. Those between 40 - 49 years also formed $29 \%$ of the overall respondents, whereas 30 - 39 years were $24 \%$ of respondents. Generally, it could be seen that majority of the respondents were less than 50 years with an overall percentage of $84 \%$ of total respondents. For Kumasi municipality, a total of 29 respondents were obtained with 10 quantity surveyors, 11 merchants and 8 contractors, whereas Accra had respondents of 49 with 18 quantity surveyors, 21 contractors, and 10 merchants. Sunyani, had 2 quantity surveyors, 3 contractors, and 12 merchants. Generally, the majority (68\%) of respondents had 5 and more years of working experience.

\subsection{Major Determinants of Prices Increase of Building Materials}

To achieve the objective of the study, it was necessary to identify the determinants of prices increase of building materials, as such the variable were obtained from literature review which was used in the determination of these major determinants. The ranking of the variables of the prices increase of building materials was estimated from the MRA statistics. The mean score for each variable was based on the Likert-type scale of 1 to 5 .

Table 1. Demographic characteristics of respondents $(n=95)$.

\begin{tabular}{|c|c|c|c|c|c|}
\hline \multirow{2}{*}{ Characteristics } & \multirow{2}{*}{$\begin{array}{c}\text { Merchants } \\
\text { (Freq.) }\end{array}$} & \multirow{2}{*}{$\begin{array}{c}\text { Contractors } \\
\text { (Freq.) }\end{array}$} & \multirow{2}{*}{$\begin{array}{c}\text { Quantity Surveyors } \\
\text { (Freq.) }\end{array}$} & \multicolumn{2}{|c|}{ Total } \\
\hline & & & & (Freq.) & $(\%)$ \\
\hline \multicolumn{6}{|l|}{ Gender } \\
\hline Male & 21 & 31 & 24 & 76 & 80 \\
\hline Female & 12 & 1 & 6 & 19 & 20 \\
\hline \multicolumn{6}{|l|}{ Age } \\
\hline$<30$ years & 4 & 10 & 15 & 29 & 31 \\
\hline $30-39$ years & 9 & 7 & 7 & 23 & 24 \\
\hline $40-49$ years & 12 & 10 & 6 & 28 & 29 \\
\hline $50-59$ years & 8 & 3 & 1 & 12 & 13 \\
\hline$\geq 60$ & 0 & 2 & 1 & 3 & 3 \\
\hline \multicolumn{6}{|l|}{ Municipality } \\
\hline Kumasi & 11 & 8 & 10 & 29 & 31 \\
\hline Accra & 10 & 21 & 18 & 49 & 51 \\
\hline Sunyani & 12 & 3 & 2 & 17 & 18 \\
\hline \multicolumn{6}{|l|}{ Experience } \\
\hline$<5$ years & 8 & 11 & 12 & 31 & 32 \\
\hline $5-9$ years & 12 & 10 & 13 & 35 & 37 \\
\hline$>10$ years & 13 & 11 & 5 & 29 & 31 \\
\hline
\end{tabular}


The results shown in Table 2 represent respondents ranking of the determinants of prices increases of building materials in Ghana. Out of the 29 variables from literature presented to the respondents, they ranked 8 as the major determinants of prices increase of building materials. Crude oil prices, energy cost,

Table 2. Mean Response Analysis (MRA) statistics of the respondents.

\begin{tabular}{|c|c|c|c|c|c|c|c|c|c|}
\hline $\mathbf{S} / \mathbf{N}$ & Causes & 1 & 2 & 3 & 4 & 5 & Total & Mean & Rank \\
\hline 1 & Crude oil prices & 0 & 3 & 4 & 50 & 28 & 85 & 4.21 & 1 \\
\hline 2 & Energy cost & 0 & 4 & 5 & 44 & 30 & 83 & 4.20 & 2 \\
\hline 3 & Local taxes and charges & 3 & 2 & 9 & 34 & 37 & 85 & 4.18 & 3 \\
\hline 4 & Cost of fuel and power supply & 1 & 6 & 8 & 30 & 38 & 83 & 4.18 & 3 \\
\hline 5 & High running cost & 1 & 3 & 7 & 43 & 30 & 84 & 4.17 & 5 \\
\hline 6 & High prices of raw materials & 1 & 4 & 10 & 35 & 34 & 84 & 4.15 & 6 \\
\hline 7 & Cost of transportation & 0 & 6 & 9 & 41 & 29 & 85 & 4.09 & 7 \\
\hline 8 & High cost of labour & 0 & 7 & 8 & 40 & 29 & 84 & 4.08 & 8 \\
\hline 9 & $\begin{array}{l}\text { Rapid depreciation of national } \\
\text { currency }\end{array}$ & 1 & 8 & 15 & 34 & 27 & 85 & 3.92 & 9 \\
\hline 10 & Interest rate and cost of finance & 5 & 4 & 9 & 47 & 18 & 83 & 3.83 & 10 \\
\hline 11 & $\begin{array}{l}\text { Government policies and } \\
\text { legislature }\end{array}$ & 4 & 7 & 15 & 35 & 24 & 85 & 3.80 & 11 \\
\hline 12 & $\begin{array}{l}\text { Maximization of profit by } \\
\text { manufacturers }\end{array}$ & 4 & 5 & 15 & 47 & 14 & 85 & 3.73 & 12 \\
\hline 13 & High tariffs & 2 & 14 & 11 & 35 & 21 & 83 & 3.71 & 13 \\
\hline 14 & $\begin{array}{l}\text { Over-dependence on imported } \\
\text { building materials }\end{array}$ & 2 & 17 & 14 & 24 & 27 & 84 & 3.68 & 14 \\
\hline 15 & Cost of plant & 3 & 13 & 20 & 34 & 13 & 83 & 3.49 & 15 \\
\hline 16 & $\begin{array}{l}\text { Declining supply or anticipated } \\
\text { shortage in supply }\end{array}$ & 2 & 18 & 20 & 24 & 19 & 83 & 3.48 & 16 \\
\hline 17 & $\begin{array}{l}\text { Behaviour of financial market } \\
\text { participants }\end{array}$ & 7 & 16 & 15 & 30 & 13 & 81 & 3.32 & 17 \\
\hline 18 & Competition & 14 & 13 & 10 & 28 & 19 & 84 & 3.30 & 18 \\
\hline 19 & $\begin{array}{l}\text { Fast-growing demand due to high } \\
\text { global economic growth }\end{array}$ & 6 & 27 & 12 & 24 & 13 & 82 & 3.13 & 19 \\
\hline 20 & Population growth & 12 & 19 & 14 & 29 & 11 & 85 & 3.09 & 20 \\
\hline 21 & Related product pricing & 8 & 16 & 23 & 33 & 3 & 83 & 3.08 & 21 \\
\hline 22 & Purchase frequency & 2 & 30 & 17 & 28 & 6 & 83 & 3.07 & 22 \\
\hline 23 & Availability of substitute & 7 & 20 & 20 & 30 & 5 & 82 & 3.07 & 22 \\
\hline 24 & $\begin{array}{l}\text { Lack or absence of indigenous } \\
\text { technology for the production of } \\
\text { building materials }\end{array}$ & 15 & 12 & 21 & 28 & 9 & 85 & 3.05 & 24 \\
\hline 25 & Price skimming & 6 & 22 & 21 & 32 & 2 & 83 & 3.02 & 25 \\
\hline 26 & Producers incentives & 8 & 21 & 23 & 27 & 2 & 81 & 2.93 & 26 \\
\hline 27 & Inadequate infrastructural facilities & 11 & 27 & 18 & 17 & 12 & 85 & 2.91 & 27 \\
\hline 28 & Business cycles & 10 & 19 & 23 & 25 & 3 & 80 & 2.90 & 28 \\
\hline 29 & Knowledge and management skills & 18 & 29 & 18 & 17 & 2 & 84 & 2.48 & 29 \\
\hline
\end{tabular}


local taxes and charges, cost of fuel and power supply, high running cost, high prices of raw materials, cost of transportation and high cost of labour with mean values $4.21,4.20,4.18,4.18,4.17,4.15,4.09$ and 4.08 respectively, were found to be the major determinants of the increase prices of building materials. This result corroborates the findings of previous studies as the mean score of the opinions of respondents in Table 2 confirms the findings of Akanni et al. [18], Windapo and Cattel [19], Ihuah [24], Mbugua [25], Kpogli [26], Bencivenga et al. [27] and Entin [28].

A close observation of the variables responsible for the increasing prices of building materials in Table 2 reveals that the crude oil price is the most significant variable. This variable is perceived to have produced a chain effect and is responsible for the ranks of the energy cost and cost of fuel and power supply as Ghanaians dependency on imports of petroleum products, which are widely used to generate energy for both production and transportation of the building materials across the nation is very high [26]. The crude oil prices, which by implication affects the cost of fuel, energy and the cost of transportation, is also perceived to have been responsible for the trend in the rising cost of building materials such as aggregates, sand, cement, reinforcement etc. as depicted in the price index of Akanni et al. [18].

Energy cost ranked second by respondents was found to be a major determinant of price increase of building materials. High energy costs have an impact on the production of most building materials since producers need to expand building material costs to wage off the increments in high energy costs [19]. A large portion of the energy utilized for the manufacturing of building materials is subject to the use of crude oil, once the expenses of crude oil heighten, then the cost required in producing energy will likewise increase, with the influence increasing the cost of other products [27].

An increase in local taxes and charges influences everything required in the production of building materials in an unexpected way. Taxes and charges imposed on suppliers by the government and its allies may be passed on to the buyers of the building materials as a cost increment. In the event that the completed item can't ingest the taxation rate, the producer or the retailer may need to bear the taxation rate or find different strategies to assimilate the expense. Moving the weight of an expense is not generally a monetarily plausible alternative, and the versatility of interest will, at last, manage the capacity to move the taxation rate to another gathering [28].

The cost of raw materials for manufacturing building materials impact on the prices of the building materials. The rising raw materials costs along with other factors such as oil, gas and energy are the key causes of increases in the prices of building materials such as cement, roofing membranes and waterproofing [29]. The raw materials required and the proposed construction details have bearing on the cost of the project [30].

Cost of transportation has been identified to be one of the contributing factors 
to the cost of building materials [31]. The increased material cost is primarily due to increased transport charges [32]. High transport and freight costs have been identified as the factors responsible for building material price increases in most African countries [19].

The high cost of labour leads to increase prices of building materials. A number of factors affect labour costs but can also boost productivity, these include better training, realistic performance-based incentives and effective organisation and supervision [33]. The employer's commitment to workers in terms of providing training and offering better rates of pay and conditions to staff is normally a worthwhile investment [30]. This invariably leads to high cost of labour which is passed on to the cost of the product.

\subsection{Relationship between Independent Variables of Prices Increase of Building Materials}

To assess the association between the independent variables of prices increase of building materials, a simple bivariate correlation was carried out and the results are shown in Table 3 which reports the intercorrelation matrix of the independent variables. Table 3 shows a Spearman correlation matrix among independent variables. The result portrayed multicollinearity among variables. A two-tailed spearmen correlation was used in order to ascertain the direction of the relationship between the variables since initially the direction was not known. Relationships between variables were either positive or negative. The highest correlation coefficient was found between fast-growing demand due to high global economic growth and over-dependence on imported building materials $(\mathrm{r}=0.607 ; \mathrm{p}<0.01)$.

Government policies and legislature had a positive relationship with some variables such as local taxes and charges $(\mathrm{r}=0.438, \mathrm{p}<0.01)$, and fast-growing demand due to high global economic growth $(\mathrm{r}=0.302, \mathrm{p}<0.01)$. This indicates that if the impact of government policies and legislature on building materials prices increases then the impact of variables such as local taxes and charges, and fast-growing demand due to high global economic growth will also increase. This is as a result of the influence of government and its policies and legislature on other variables within the same jurisdictions as such a higher impact accruing from that will lead to the same impact from the other related variables.

The variable interest rate and cost of finance had a direct relationship between cost of fuel and power supply $(\mathrm{r}=0.407, \mathrm{p}<0.01)$, inadequate infrastructural facilities $(\mathrm{r}=313, \mathrm{p}<0.1)$, cost of plant $(\mathrm{r}=0.560, \mathrm{p}<0.01)$, business cycles $(\mathrm{r}=$ 0.360, $\mathrm{p}<0.01)$, knowledge and management skills $(\mathrm{r}=0.331, \mathrm{p}<0.01)$, and population growth $(\mathrm{r}=0.385, \mathrm{p}<0.01)$. This implies that in considering their influence on pricing, they all have the same level of impact as such they all have the iota of impact on building materials prices. Interest rate and cost of finance again had a negative or an inverse relationship between high prices of raw materials. The inverse relationship implies that inculcating a full effect of one on 


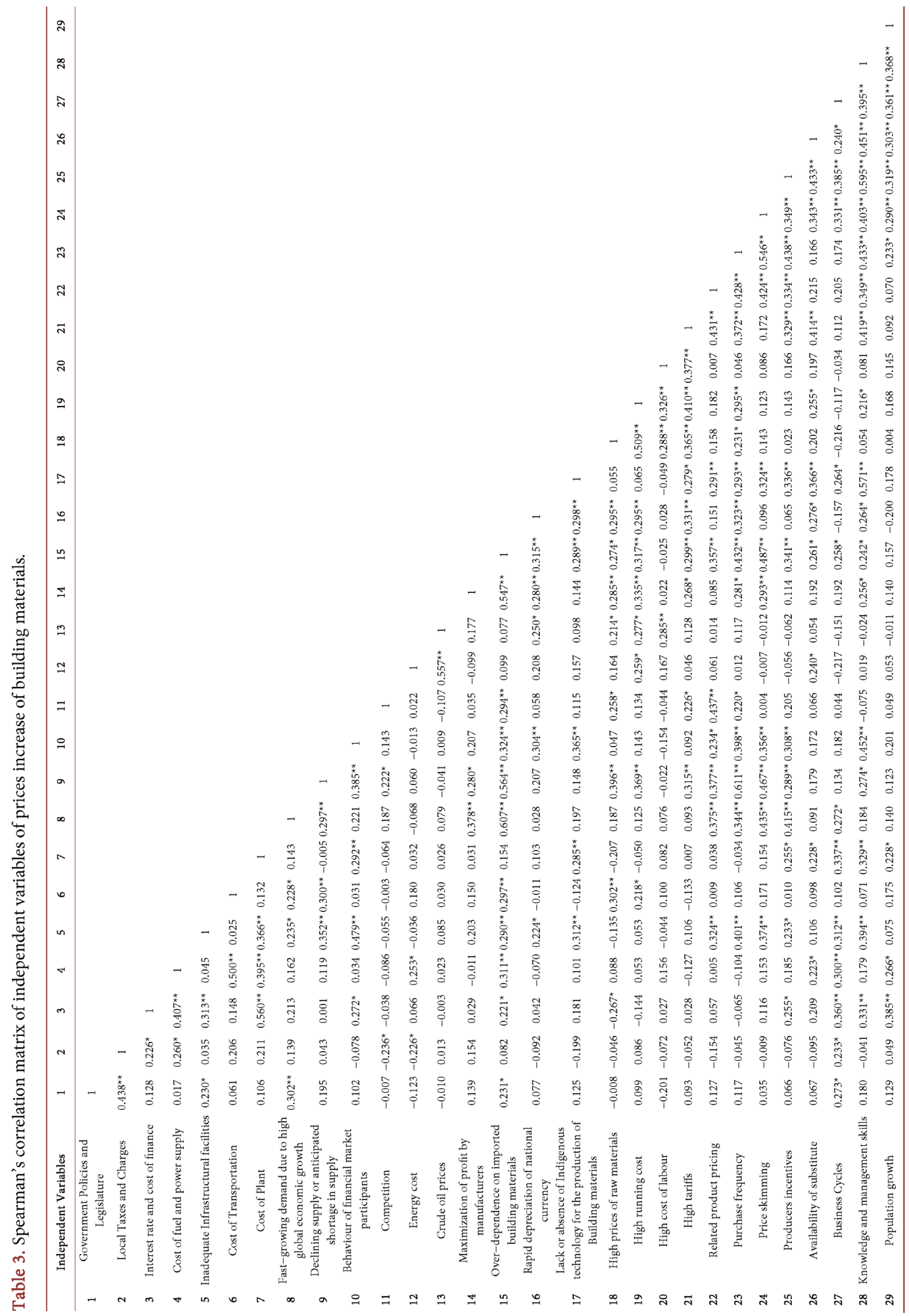


prices will result in a reduction of the others influence on prices of building materials as such as ones' impact increases the others impact decreases.

Besides, there was a substantial relationship between fast-growing demand due to a high global economic growth and over-dependence on imported building materials $(\mathrm{r}=0.607, \mathrm{p}<0.01)$. This means that when the demand for building materials increase as a consequence of the fast growing rate of economic factors, most people will then tend to highly depend on imported building materials as such their impacts and vice versa [34]. Another essential positive relationship was found between declining supply or anticipated shortage in supply and over-dependence on imported building materials $(\mathrm{r}=0.564, \mathrm{p}<0.01)$. Once producers fail to supply the quantum of building materials required or when the supplies of construction materials are reduced, individual or customers will tend to rely on imported building materials to be able to see the amount of quantity required [34]. Crude oil prices were found to be the major determinant on the price level, caused a confident relation with energy cost $(\mathrm{r}=0.557, \mathrm{p}<0.01)$. Most of the energy used for the production of building materials is dependent on the utilization of crude oil as such once the costs of crude oil escalate then the cost involved in providing energy will also increase [27].

Maximization of profit by the manufacturers as one of the determinants also had a positive relation on over dependence on imported building materials $(\mathrm{r}=$ $0.547, \mathrm{p}<0.01)$ implying that, when manufacturers decide to increase their net margins on building materials, the prices of the products will increase as such consumers will tend to rely more on imported products as that leads to less price than the ones being made within their locality. Also, the positive relationship between high running cost and high prices of raw materials was known $(\mathrm{r}=$ $0.509, \mathrm{p}<0.01$ ). Raw materials are part of the running cost of production as such the cost of raw materials will consequently lead to high running cost [30]. Price skimming and purchase frequency are positively correlated $(\mathrm{r}=0.546, \mathrm{p}<0.01)$. With price skimming having to do with the setting of a price at a higher level and later reducing it over time, consumers purchase frequency will determine how long this price would be reviewed as time goes on [35]. This implies that the lower the purchase frequency of consumers, the higher it is possible to maintain the high price for a specific period of time so as not to run loss and vice versa. Producers of building materials would inevitably inculcate an iota of their knowledge on management in the pricing of building materials as such there was a positive correlation between producers' incentives and knowledge and management skills $(\mathrm{r}=0.595, \mathrm{p}<0.01)$.

\section{Conclusions}

This study aimed at identifying the major determinants of prices increase of building materials on Ghanaian construction market, and also to assess the relationship between the independent variables of prices increase. 29 variables obtained from the literature were presented to the respondents in the questionnaire, 
out of which 8 variables were ranked by the respondents as the major determinants of prices increase of building materials in Ghana. The major determinants are crude oil prices, energy cost, local taxes and charges, cost of fuel and power supply, high running cost, high prices of raw materials, cost of transportation and the high cost of labour. The study further found multicollinearity relationship among variables of prices increase, of which the highest correlation coefficient was found between fast-growing demand due to high global economic growth and over-dependence on imported building materials $(r=0.607 ; \mathrm{p}<0.01)$.

The results of this study are expected to assist construction industry practitioners to focus attention on the identified determinants so as to help control the prices of building materials. The Government could also consider the results of this study to help in putting in place legislation to control the identified determinants, in order to curb the increasing prices of building materials. It is recommended that further research should be carried out to determine the control measures of increasing prices of building materials in Ghana.

\section{References}

[1] Mansur, S.A., Abdul Hamid, A.R. and Yusof, N.A. (2016) Rising Trend in Construction Cost and Housing Price. Journal of Advanced Research in Business and Management Studies, 3, 94-104.

[2] Nadramia, T.J. (2013) Key Credit Factors for the Building Materials Industry. RatingsDirect. http://www.standardandpoors.com/ratingsdirect

[3] Jonsson, J. (2017) Construction Cost Index for buildings. Statistical agency and producer. Statistics Sweden, Urban Management and Tourism.

[4] Slowey, K. (2017) The Price "U-Turn": What Rising Material Costs Mean for Construction. Construction Dive.

https://www.constructiondive.com/news/the-price-u-turn-what-rising-material-cos ts-mean-for-construction/438488/

[5] Reyes, C.B. (2017) Cost of Home Building Materials Rising Rapidly. Economic Factors, Real Estate Investment, Real Estate News.

http://journal.firsttuesday.us/cost-of-home-building-materials-rising-rapidly/58962/

[6] Windapo, A., Odediran, S., Moghayedi, A., Adediran, A. and Oliphant, D. (2017) Determinants of Building Construction Costs in South Africa. Journal of Construction Business and Management, 1, 8-13.

[7] Mosha, A. (2011) Government Policies to Enhance Access to Housing and Financial Stability Experiences from Other Countries. Paper prepared for the Bank of Namibia Housing Symposium.

[8] Pashardesa, P. and Savva, C.S. (2009) Factors Affecting House Prices in Cyprus: 1988-2008. Cyprus Economic Policy Review, 3, 3-25

[9] Wagura, T.J. (2013) Determinants of Housing Supply in Kenya. Post Graduate Diploma Thesis, School of Built Environment, University of Nairobi, Kenya.

[10] Oladipo, F.O. and Oni, O. J. (2012) A Review of Selected Macroeconomic Factors Impacting Building Material Prices in Developing Countries-A Case of Nigeria. Ethiopian Journal of Environmental Studies and Management, 5, 131-137.

https://doi.org/10.4314/ejesm.v5i2.3 
[11] Huan, Z. and Jianhua, Z. (2013) Analysis of Factors to Cause the Price Change of Building Materials. Advanced Materials Research, 683, 668-671. https://doi.org/10.4028/www.scientific.net/AMR.683.668

[12] Rajaprabha, R., Velumani, P. and Jayanthi, B. (2016) Factors Affecting the Cost of Building Material in Construction Projects. International Journal of Science and Engineering Research, 4, 1-6.

[13] Sunde, T. and Muzindutsi, P.F. (2017) Determinants of House Prices and New Construction Activity: An Empirical Investigation of the Namibian Housing Market. The Journal of Developing Areas, 51, 390-407. https://doi.org/10.1353/jda.2017.0080

[14] Warsame, A. (2006) Supplier structure and Housing Construction Costs. Report 5:73, Building and Real Estate Economics, Department of Infrastructure, Royal Institute of Technology, Stockholm.

[15] Danso, H. and Antwi, J.K. (2012) Evaluation of the Factors Influencing Time and Cost Overruns in Telecom Tower Construction in Ghana. Civil and Environmental Research, 2, 15-24. http://www.iiste.org/Journals/index.php/CER

[16] Danso, H. (2013) Building Houses with Locally Available Materials in Ghana: Benefits and Problems. International Journal of Science and Technology, 2, 225-231.

http://www.journalofsciences-technology.org/archive/2013/feb_vol_2_no_2/feb_20 13.php

[17] Glindro, E. T., Subhanij, T., Szeto, J. and Zhu, H. (2008) Determinants of House Prices in Nine Asia-Pacific Economies. https://ideas.repec.org/a/ijc/ijcjou/y2011q3a6.html

[18] Akanni, P., Oke, A. and Omotilewa, O. (2014) Implications of Rising Cost of Building Materials in Lagos State Nigeria. SAGE Open, 4, 1-7. https://doi.org/10.1177/2158244014561213

[19] Windapo, A. and Cattell, K. (2012) Examining the Trends in Building Material Prices: Built Environment Stakeholders' Perspectives. Management of Construction. Research to Practice, 1, 187-201.

https://www.irbnet.de/daten/iconda/CIB_DC25658.pdf

[20] Tupenaite, L., Kanapeckiene, L. and Naimaviciene, J. (2016) Determinants of Housing Market Fluctuations: Case Study of Lithuania. Procedia Engineering, 172, 1169-1175. https://doi.org/10.1016/j.proeng.2017.02.136

[21] Glen, S. (2015) Snowball Sampling: Definition, Advantages and Disadvantages. http://www.statisticshowto.com/snowball-sampling/

[22] Straub, D., Boudreau, M. and Gefen, D. (2004) Validation Guidelines for IS Positivist Research. Communications of the Association for Information Systems, 13, 380-427.

[23] Danso, H. (2012) Construction Workers' Satisfaction with Work Provision Requirement Dimensions in Ghana's Construction Industry. International Journal of Engineering and Technology, 2, 1613-1619. http://www.iet-journals.org/archive/2012/sep_vol_2_no_9/sep_2012.php

[24] Ihuah, P.W. (2015) Building Materials Cost Increases and Sustainability in Real Estate Development in Nigeria. African Journal of Economic and Sustainable Development, 4, 218-233. https://doi.org/10.1504/AJESD.2015.071907

[25] Mbugua, G. (2016) A Study on Effective Building Material Management by Kenyan Local Contractors: Emphasis on Procurement, A Case Study of Nairobi County. 
The University of Nairobi, Nairobi.

http://realestates.uonbi.ac.ke/sites/default/files/cae/artsdesign/realestates/anthony\% 20mbugua\%20final.pdf

[26] Kpogli, C. (2014) The Impact of Oil Price Changes on Inflation in Ghana. M. Phil, University of Ghana, Ghana.

[27] Bencivenga, C., Sargenti, G. and D’Ecclesia, R. (2010) Energy Markets: Crucial Relationship between Prices. In: Corazza, M. and Pizzi, C., Eds., Mathematical and Statistical Methods for Actuarial Sciences and Finance, Springer, Berlin, 23-32. https://doi.org/10.1007/978-88-470-1481-7_3

[28] Entin, S.J. (2004) Tax Incidence, Tax burden, and Tax Shifting: Who Really Pays the Tax? Heritage Foundation, Washington DC.

[29] Iyengar, S.P. (2011) High Raw Material Costs to Hit Q4 Profits of Cement Companies. http://www.thehindubusinessline.com/

[30] Cunningham, T. (2013) Factors Affecting the Cost of Building Work-An Overview. Dublin Institute of Technology, Dublin, 1-21.

[31] Danso, H. (2015) Use of Agricultural Waste Fibres as Enhancement of Soil Blocks for Low-Cost Housing in Ghana. PhD, School of Civil Engineering and Surveying, University of Portsmouth, Portsmouth. http://ethos.bl.uk/OrderDetails.do?uin=uk.bl.ethos.686958

[32] Sinclair, N., Artin, P. and Mulford, S. (2002) Construction Cost Data Workbook. Proceedings of Conference on the International Comparison Program, Washington DC, 11-14 March 2002, 1-29.

[33] Seeley, I.H. (1996) Building Economics. 4th Edition, Basingstoke Hampshire, Macmillan.

[34] Bamford, C. and Grant, S. (2015) Cambridge International AS and A-Level Economics Course Book. Cambridge University Press, Cambridge, 96.

[35] Dudu, O. and Agwu, M. (2014) A Review of the Effect of Pricing Strategies on the Purchase of Consumer Goods. International Journal of Research in Management, Science and Technology, 2, 88-99. 